\title{
Kamu Kurumlarında İç Denetim Faaliyetlerinin Yürütülmesinde Karşılaşılan Başlıca Sorunların Tespiti: Kamu İç Denetçilerine Yönelik Bir Araştırma*
}

\author{
Reşat KARCIOĞLU**, Ersin KURNAZ***
}

Öz

Bu çalışmada kamu kurumlarında iç denetim faaliyetlerinin yürütülmesinde karşılaşılan başlıca sorunların tespiti ve hangi kurumlarda ne tür sorunların ön plana çıktığının belirlenmesi amaçlanmaktadır. Bu kapsamda kamu iç denetçilerine bir anket uygulanmıştır. Sonuç olarak, kamu kurumlarında iç denetim faaliyetlerinin yürütülmesinde birçok sorunla karş̧laşıldığı tespit edilmiştir. Ayrıca genel bütçeli kamu kurumlarında, iç denetimde genel bağımsızlık ve iç denetçilerin özlük haklarıyla ilgili sorunların, mahalli idarelerde ise iç denetçilerin görev, yetki ve statüleriyle ilgili sorunların ön plana çıktığı sonucuna ulaşılmıştır.

Anahtar Kelimeler: İç Denetim, Güvence, Danışmanlık, Kamu Kurumları, Avrupa Birliği.

\section{Determination of the Main Problems Encountered in the Execution of Internal Audit Activities in Public Institutions: An Investigation on Public Internal Auditors}

\section{Abstract}

In this study, it is aimed to determine the main problems encountered in the execution of internal audit activities in public institutions and to determine what problems are leading to which institutions. In this context, a questionnaire was conducted to public internal auditors. As a result, it has been found that many

\footnotetext{
Özgün Araştırma Makalesi (Original Research Article)

Geliş Tarihi: 26.07.2017 Kabul Tarihi: 26.12.2017

DOI: http://dx.doi.org/10.17336/igusbd.388023

${ }^{*} \mathrm{Bu}$ çalışma doktora tezinden uyarlanmıştır.

** Prof. Dr., Atatürk Üniversitesi, İ̈BF, İşletme Bölümü, Erzurum, Türkiye, E-posta: rkarci@atauni.edu.tr ORCID ID http://orcid.org/0000-0002-0903-3816

${ }^{* * *}$ Yrd. Doç. Dr., Bayburt Üniversitesi, SBF, Sağllk Yönetimi Bölümü, Bayburt, Türkiye, E-posta: ersinkurnaz@bayburt.edu.tr ORCID ID https://orcid.org/0000-0002-6787$\underline{5368}$
}

Sayfa/Page | 67

IGU J. Soc. Sci., 4 (2), Spec. Iss. of ICEFM 2017, pp. 67-88. 
Sayfa/Page | 68

İGÜ Sos. Bil. Derg., 4 (2), ICEFM 2017 Özel Sayısı, ss. 67-88. problems are encountered in carrying out internal audit activities in public institutions.

In addition to general budgetary public institutions have reached the foreground of problems related to general independence in internal auditing and the personal rights of internal auditors and in the local administrations problems related to the duties, powers and statutes of internal auditors.

Keywords: Internal Audit, Assurance, Consultancy, Public Institutions, European Union.

\section{Giriş}

İç denetimin zamanla geçirmiş olduğu değişim ve gelişim sürecine bakıldığında, 1980'lere kadar işletmelerin mali tablolarının doğruluğu, yapılan faaliyetlerin yasal mevzuata uygunluğu, hata ve hilelerin tespiti gibi uygulamaları kapsayan geleneksel denetim anlayışının etkin olduğu görülmektedir. 2000'li yıllara gelindiğinde ise, işletmelerin amaç ve hedeflerine ulaşması için tüm faaliyetlerin denetimini kapsayan ve sınırlı denetim kaynaklarının kullanımını önemlilik derecesi yüksek olan riskli faaliyetlere göre tahsis eden risk odaklı denetim anlayışı kabul görmeye başlamıştır. Tüm bu gelişmeler de iç denetim fonksiyonunun yönünü ve çehresini değiştirmiştir.

Günümüzde geleceğe dönük ve kurumlara değer katmayı amaçlayan bir denetim anlayışının benimsenmesi, iç denetçilerin yetki ve sorumluluğunun artması, iç denetimin faaliyet alanın genișlemesi, iç kontrol ve kurumsal risk yönetimi sistemleriyle entegre çalışılmaya başlanması gibi gelişmeleri beraberinde getirmiştir. Bu durum da iç denetim faaliyetlerinin yürütülmesi esnasında iç denetçileri bazı sorunlarla kașı karşıya bırakmıștır. Bu kapsamda söz konusu çalışma ile kamu kurumlarında geniş bir uygulama alanı bulunan iç denetim faaliyetlerinin yürütülmesi aşamasında karşılaşılan başlıca sorunların tespiti ve hangi kurumlarda ne tür sorunların ön plana çıtığının belirlenmesi amaçlanmaktadır. Bu amaç doğrultusunda Türkiye'de kamu sektöründeki iç denetçilere yönelik bir anket çalıșması yapılarak araștırma hakkında değerlendirmelerde bulunulmuştur.

\section{1. İç Denetimin Tanımı ve Kapsamı}

İç denetim, kuruluşların yönetiminde önemli bir unsur olarak gelişim gösteren, dinamik bir yapıya sahiptir. 2000'li yıllarda Enron ve WorlCom gibi büyük şirketlerin, iç denetim sistemlerindeki eksikliklerden kaynaklı sebeplere bağlı olarak iflas etmeleri, iç denetimin önemini belirgin bir şekilde artırmıștır. Bunun üzerine düzenleyici kuruluşlar, şirketlerin etkin bir iç denetim birimine sahip olmalarını sağlamak için bir takım çalışmalar 
yapmışlardır. ${ }^{1}$ Aynı zamanda yaşanan bu büyük skandallar, birçok şirketin iç kontrol sisteminin ve iç denetim fonksiyonunun üstleneceği rollere odaklanmasına neden olmuştur. Bu durum da bazı ülkelerde bu konu ile ilgili yasal düzenlemelerin yapılmasını hızlandırmıştır. ${ }^{2}$

İç denetime duyulan ihtiyacın zamanla artması, iç denetimin faaliyet alanının geniş olması ve işletmeler içerisindeki konumunun farklılık göstermesi gibi nedenler, iç denetim için kapsamlı bir tanımın yapılmasını zorlaştırmaktadır. Bu kısıtlar çerçevesinde iç denetim, bir organizasyonun faaliyetlerini incelemek ve değerlendirmek amacıyla, organizasyon içinde oluşturulmuş bağımsız bir değerlendirme işlevi gören, çalışanların sorumluluklarını yerine getirmelerine yardımcı olan ve onlara incelediği faaliyetlerle ilgili analiz ve değerlendirmelerinin sonuçlarını sunarak, tavsiyelerde bulunan bir fonksiyon olarak tanımlanabilir. ${ }^{3}$

Ancak daha sonra küreselleşmenin de etkisiyle işletmelerin giderek karmaşık bir yapıya bürünmesi, iç denetimden beklentilerin de değişmesine yol açmıştır. ${ }^{4}$ Bu değişimleri kapsayacak tanım, İç Denetçiler Enstitüsü (IIA) tarafından yapılmış ve bu tanım tüm dünyada kabul görerek uluslararası bir nitelik kazanmıştır. IIA'in yapmış olduğu tanıma göre; “İç denetim, kurumun faaliyetlerine değer katmak ve bunları geliştirmek amacıyla tasarlanmış, bağımsız, nesnel güvence sağlama ve danışmanlık faaliyetidir. Risk yönetimi, kontrol ve yönetim süreçlerinin etkililiğini, sistematik ve disiplinli bir yaklaşımla değerlendirip geliştirerek kurumun hedeflerine ulaşmasına yardımcı olur". 5

İç denetimin tanımında geçen "güvence" ve "danışmanlık" kavramlarını biraz daha ayrıntılı olarak açıklamak, iç denetimin daha iyi anlaşılmasını sağlayacaktır.

Güvence; iç denetimin faaliyet alanına giren risk yönetimi, iç kontrol ve kurumsal yönetim gibi konuların iç denetim perspektifi çerçevesinde değerlendirerek, değerlendirme sonuçlarının üst yönetim ve diğer çıkar gruplarına sunulmasıdır. İç denetçilerin denetim sürecinde bağımsız ve tarafsız olmaları, kuşkusuz güvence hizmetlerine değer katacaktır. Burada açıklanması gereken bir konuda şudur; iç denetçilerin vermiş olduğu güvence kesinlikle mutlak bir güvence değil, sadece makul bir güvence niteliği

\footnotetext{
${ }^{1}$ Joseph V. Carcello, Dana R. Hermanson, K. Raghunandan, "Factors Associated with U.S. Public Companies' Investment in Internal Auditing", Accounting Horizons, 19(2), June 2005, s.69.

2 Marika Arena, Michela Arnaboldi, Giovanni Azzone, "Internal audit in Italian Organizations A Multiple Case Study", Managerial Auditing Journal, 21(3), 2006, s. 275.

3 Nuran Cömert Doyrangöl, "İşletme Çevresindeki Olumsuz Gelişmeler Karşısında İç Denetimin Yeri ve Önemi”, Mali Çözüm Dergisi, Sayı: 60, 2002, s.3.

${ }^{4}$ Giselle Bou-Raad, "Internal Auditors and A Value-Added Approach: The Business Regime”, Managerial Auditing Journal, 15(4), 2000, s. 182.

${ }^{5}$ www.theiia.org, Erişim Tarihi:01.10.2015.
}

Sayfa/Page | 69

IGU J. Soc. Sci., 4 (2), Spec. Iss. of ICEFM 2017, pp. 67-88. 
Sayfa/Page $\mid 70$

İGÜ Sos. Bil. Derg., 4 (2), ICEFM 2017 Özel Sayısı, ss. $67-88$

taşımaktadır. Danışmanlık ise; herhangi bir yönetsel sorumluluk üstlenmediği halde, ișletme faaliyetlerinin işleyișiyle ilgili analiz yapma şansına sahip olan iç denetçilerin, işletmenin faaliyetlerini geliştirmek ve onlara değer katmak için kapsam ve niteliğini denetledikleri kişilerle ortak olarak belirledikleri istişari faaliyetler anlamındadır. Planlı iç denetim faaliyetleri dışında yer alan danışmanlık faaliyetleri, özellikle yeni iş süreçlerinin tasarımı aşaması ile mevcut süreçlerin geliştirilmesi ve çalışanların risk yönetimi, iç kontrol, kurumsal yönetim gibi konularda yoğunlaşmaktadır. ${ }^{6}$

İç denetimin kapsamı işletmenin yapısına, büyüklügüne ya da dış çevre yapısına bakılmaksızın faaliyetlerinin tümünü içermektedir. $\mathrm{Bu}$ açıdan bakıldığında, işletme bünyesindeki tüm sistemler, süreçler, etkinlikler iç denetçinin değerlendirmelerine tabidir. IIA tarafından yapılan iç denetim tanımından hareketle iç denetim; kurumsal risk yönetimi, iç kontrol sistemi ve kurumsal yönetişim süreçlerinin sistemli ve disiplinli bir şekilde incelenerek değerlendirilmesini de kapsamaktadır. Burada ifade edilmesi gereken önemli konulardan birisi de şudur; hilelerin, usulsüzlüklerin ve dolandırıcılıkların ortaya çıkarılması ve önlenmesi gibi vakalar iç denetçinin sorumlulukları arasında yer almamaktadır. Bu gibi olayların tespiti ve önlenmesi yönetimin sorumluluğundadır. Burada iç denetçilerin rolü, yönetim tarafından bu tür riskleri yönetmek için oluşturulan kontrol faaliyetlerine yönelik denetim program ve prosedürlerini hazırlayarak takibini yapmaktır. ${ }^{7}$

Günümüzde işletmelerin ihtiyaçları dikkate alındığında iç denetim, geleneksel denetim anlayışını kapsamakla birlikte, gelecek odaklı bir yaklaşım içerisinde, işletmenin amaç ve hedeflerine ulaşmak için gerçekleştirilen faaliyetlerin verimli ve etkili bir șekilde uygulandığı yönünde güvence vermeye odaklanan bir bakış açısına sahip olmalıdır. ${ }^{8}$ İç denetim faaliyetlerinin kapsamının genişlemesi, iç denetçilerin bakış açılarını, proaktif bir anlayış içerisinde risklere odaklanan ve sürekli olarak değer katmayı amaçlayan denetim yaklaşımlarına yöneltmiştir.

\section{Türkiye'de Kamu Kurumlarında İç Denetimin Oluşum ve Gelişim}

\section{Süreci}

1999 tarihlerinde, Helsinki'de yapılan Avrupa Birliği Devlet ve Hükümet Başkanları Zirvesinde, Türkiye'nin Avrupa Birliği'ne (AB) adaylığı resmen tescillenmiştir. Adaylık statüsünün elde edilmesiyle beraber Türkiye ile $\mathrm{AB}$ arasında yeni bir dönem başlamıştır. Bu süreçte yer alan kriterler gereği kamu

${ }^{6}$ M. Cemil Arslan, Büyükşehir Belediyelerinin İç Denetim Uygulamaları, T.C. Marmara Belediyeler Birliği Yayını, Yayın No: 82, İstanbul 2014, s.59-60.

${ }^{7}$ M. Didem Doğmuş, Avrupa Birliği'nde İç Denetim Sistemi, Maliye Bakanlığı Avrupa Birliği ve Dış İlişkiler Dairesi Başkanlığı Araștırma ve İnceleme Serisi: 2, Ankara 2010, s.26-27.

${ }^{8}$ Deniz Barlas Hüner, Bağımsız Denetimde İç Kontrol ve İç Denetimin Rolü, (Yayımlanmamış Yüksek Lisans Tezi), Okan Üniversitesi, Sosyal Bilimler Enstitüsü, İstanbul, 2014, s.93-94. 
kurumları kendilerini yenileme imkânını elde etmişlerdir. ${ }^{9}$ Bu yeniliklerden birisi de kamu kurumlarında iç denetim sistemidir.

AB'nin iç denetime ilişkin standart bir mevzuatı bulunmamaktadır. Birliğe üyeliği bulunan ülkelerin, iç denetim sistemleri konusundaki yaklaşım farklılıkları da bunu göstermektedir. AB, kendi ilke ve standartları ile uyumlu uluslararası standartların kabul edilip uygulanmasını, her türlü yetki, görev ve sorumlulukların yasayla belirlendiği bir denetim sisteminin oluşturulmasını üye ülkelerden istemektedir.10

AB'de denetim güney model (merkeziyetçi) ve kuzey model (âdem-i merkeziyetçi) şeklinde iki motiften oluşur. Güney model de iç denetim, Maliye Bakanlığı'na bağlı olarak çalışan denetçiler tarafından ifa edilir. Bu model de daha çok, ön mali kontrolü yapan birim üzerinde odaklanılır. Güney model esas alınarak yapılan iç denetim faaliyeti, mali denetim ağırlıklı olarak yapılır. $\mathrm{AB}$ üyesi olup da, güney modeli uygulayan bazı ülkeler; Fransa, Portekiz, İspanya ve Lüksemburg'dur. Kuzey model de ise, kamu kaynaklarını kullanma hususunda sorumluluk tümüyle harcamacı kamu idaresine verilmiştir. Aynı zamanda bu model de geleneksel nakit yönetiminden, modern bütçe yönetimine doğru bir geçiş yaşanmaktadır. Söz konusu modelde, bakanlık üst yöneticisi ile harcama yetkilisinin sorumluluğu büyük önem arz etmektedir. Burada iç denetim faaliyeti kamu idarelerine bağlı iç denetçiler tarafından gerçekleştirilmektedir. İç denetçi kaynakların etkili, ekonomik ve verimli kullanımından emin olmak için ilgili usul ve esaslara, yönetim politikalarına, kontrol sistemlerine ve yasalara yoğunlaşır. İç denetim, güney modelde mali denetim ağırlıklı iken, kuzey modelde mali denetimle birlikte sistem, performans ve bilgi sistemleri denetimi ağırlıklıdır. İngiltere ve Hollanda gibi ülkeler, kuzey modeli benimseyen ülkeler arasında yer almaktadır.11 Türkiye'de ise, daha çok yönetimin sorumluluğunu ön plana çıaran ve 5018 sayılı Kamu Mali Yönetimi ve Kontrol Kanunu (KMYKK) ile yasal alt yapısı oluşturulan, kuzey modeli benimsenmiştir.

AB ile yapılan müzakerelerde iç denetim, Mali Kontrol (32. Fassl ) başlığı altında ele alınmıştır. AB Türkiye'deki kamu idarelerinin mali kontrol sistemine ilişkin ilk çalışmasını, 13-14 Nisan 2000 tarihlerinde Ankara'da yapmıştır. Çalışma neticesinde, kamu iç mali kontrol sisteminde, hem kavramsal hem de işlevsel düzeyde ciddi eksikliklerin olduğu ve bu alanla ilgili yasal bir düzenlemenin de olmadığı ifade edilmiştir. Aynı zamanda denetim alanındaki yetki ve sorumlulukların da açık bir şekilde belirtilmediği yönünde tespitlerde bulunulmuştur. ${ }^{12}$

\footnotetext{
9 Şener Gönülaçar, “İç Denetimin Bürokratik Serencamı”, Mali Hukuk Dergisi, Sayı: 35, Mayıs-Haziran 2008, s.6.

10 Gönülaçar, 2008: 3.

${ }^{11}$ Şener Gönülaçar, "İç Denetimde Hedefler ve Beklentiler", Mali Hukuk Dergisi, Sayı: 130, Temmuz 2007, s.6.

12 Gönülaçar, 2008: 7.
}

Sayfa/Page | 71

IGU J. Soc. Sci., 4 (2), Spec. Iss. of ICEFM 2017, pp. 67-88. 
Sayfa/Page $\mid 72$

İGÜ Sos. Bil. Derg., 4 (2), ICEFM 2017 Özel Sayısı, ss. 67-88.

Türkiye'de kamu kurumlarında iç denetim alanında yaşanan en son gelişmeleri, AB tarafından her yıl düzenli olarak yayınlanan ilerleme raporlarında görmek mümkündür. Bu kapsamda 2016 yılı ilerleme raporunda iç denetimle ilgili yer alan tespitlerden bazıları şunlardır: ${ }^{13}$

- İç denetim rehberi ve etik davranış kuralları ile Merkezi Uyumlaştırma Birimi tarafından hazırlanan kılavuzlar mevcuttur.

- İç denetim birimi oluşturması gereken 383 kurumun 252'si bunu yerine getirmiştir.

- Bugüne kadar, genel yönetim kurumlarındaki iç denetçi kadrolarının $\% 46$ 'sı doldurulmuştur.

- İç denetçilerin \%19’u uluslararası sertifikaya sahiptir.

- İç denetimin yönetici düzeyinde sahiplenilmesi zayıf kalmaya devam etmektedir.

Burada yer alan tespitlerden en önemlisi iç denetimin üst yönetici tarafından sahiplenilmemesi konusudur. Yeni mali yönetim ve kontrol sisteminde üst yönetici, iç denetim faaliyetlerinde etkinliğin ve verimliliğin sağlanması hususunda çok önemli bir role sahiptir. Dolayısıyla üst yöneticinin bu konuda gerekli hassasiyeti göstermemesi, iç denetim faaliyetlerinde birçok sorunun ortaya çıkmasına yol açabilir.

\section{3. İç Denetim Faaliyetlerinin Yürütülmesinde Karşılaşılan Başlıca Sorunların Belirlenmesine Yönelik Bir Uygulama}

\subsection{Araștırmanın Amacı}

Türkiye'nin AB'ye üyelik süreci kapsamında hazırlanan 5018 sayılı KMYKK'nın 2003 yılında yürürlüğe girmesiyle birlikte, kamu kurumları iç denetim sistemiyle tanışmışlardır. Yeni kamu mali yönetimi ve kontrolü anlayışı çerçevesinde oluşturulan iç denetim birimleri hem nitelik açısından hem de nicelik açısından daha aktif ve daha fonksiyonel bir yapıya bürünmüştür. Bu kapsamda söz konusu çalışma ile kamu kurumlarında geniş bir uygulama alanı bulunan iç denetim faaliyetlerinin yürütülmesi aşamasında karşılaşılan başlıca sorunların tespiti ve hangi kurumlarda ne tür sorunların ön plana çlktığının belirlenmesi amaçlanmıştır.

\subsection{Araştırmanın Önemi}

Kamu kurumlarında iç denetim sistemine geçilmesiyle birlikte, sadece mali nitelikli faaliyetlerin denetimini öngören teftiş sistemi yerini, tüm faaliyetlerin denetimini kapsayan modern iç denetim olarak da adlandırılan risk odaklı iç denetim sistemine bırakmıştır. Bu sistemle beraber kamu kurumlarında iç denetim faaliyetlerinin uygulama alanı daha da genişlemiştir.

${ }^{13}$ www.ab.gov.tr, Erișim Tarihi: 11.06.2016. 
Bu durumda iç denetim faaliyetlerinin etkin bir şekilde yürütülmesinde son derece önemli olan genel ve fonksiyonel bağımsızlık, raporlama, görev, yetki ve statü gibi konuların önemini artırmıştır. Bu çalışma, söz konusu konulara gerek ilgili yasal mevzuatta gerekse uygulama esnasında ne kadar yer verildiğinin ortaya konması açısından büyük bir önem taşımaktadır. Ayrıca kamu kurumlarına yönelik kapsamlı bir çalışma olduğu için, hangi kurumlarda ne tür iç denetim uygulama sorunlarının daha belirgin olduğunun tespit edilmesi açısından da ayrı bir önem arz etmektedir.

\subsection{Araștırmanın Kapsamı ve Yöntemi}

Araştırmada, Türkiye'deki kamu kurumlarının iç denetim sistemlerinde karşılaşılan başlıca sorunların tespit edilmesi amaçlandığından anket çalışması, SGK'lar hariç diğer tüm kamu kurumlarında çalışan iç denetçilerine yapılmıştır. Araştırmanın yapıldığı dönem itibariyle araştırma kapsamındaki kamu kurumlarında istihdam edilen iç denetçi sayısı, IDKK'nın 29.02.2016 tarihli kurul kayıtlarına göre 924 kişidir. Çalışmada örneklem seçimi yapılmayıp, ana kütlenin tamamına ulaşılması hedeflenmiștir.

Veri toplamada anket yöntemi kullanılmıştır. Araştırmanın amaçları doğrultusunda anket soruları hazırlanırken, uluslararası iç denetim standartlarından, kamu iç denetim rehberinden, 5018 sayılı KMYKK'dan ve N. Zarifi GÜRKAN'nın (2009) çalışmasından yararlanılmıştır. Çalışmada verilerin toplanmasında kullanılan anket forumları, iç denetçilere Maliye Bakanlığı'nın Antalya'da 03-15 Mayıs 2016 tarihleri arasında düzenlediği bir eğitim esnasında uygulanmıştır. Araştırmanın ana kütlesini oluşturan 924 iç denetçinin 592'sinden geçerli geri dönüş alınabilmiştir. Bu oran \%64'lük bir geri dönüş oranına tekabül etmektedir.

Anketlerden elde edilen verilerin analizinde SPSS programı kullanılmıştır. $\mathrm{Bu}$ program vasıtasıyla frekans, yüzde, ortalama gibi tanımlayıcı istatistiki yöntemler kullanılmıştır. Ayrıca Kruskal-Wallis Testi ile çalışmanın hipotezleri test edilmiştir.

\section{Araştırma Bulgularının Değerlendirilmesi}

Araştırmaya katılan iç denetçilere ait demografik verilerin ve konu kapsamındaki diğer bulguların değerlendirmeleri bu kısımda sunulmaktadır.

\subsection{Demografik Bilgilere Yönelik Bulguların Analizi}

Anketteki soruların sıralamasına uygun olarak öncelikle katılımcılarla ilgili demografik bilgiler Tablo 1'de yer almaktadır. 
GÜ Sos. Bil. Derg.,

4 (2), ICEFM 2017

Tablo 1: Katılımcılara İlişkin Demografik Bilgiler

\begin{tabular}{|c|c|c|c|}
\hline Demografik Özellik & & $\mathbf{N}$ & $\%$ \\
\hline \multirow{3}{*}{ Cinsiyet } & Kadın & 73 & 12,3 \\
\hline & Erkek & 519 & 87,7 \\
\hline & Toplam & 592 & 100 \\
\hline \multirow{6}{*}{ Yaş } & 30 ve altı & - & - \\
\hline & $31-39$ arası & 205 & 34,6 \\
\hline & $40-49$ arası & 222 & 37,5 \\
\hline & $50-59$ arası & 135 & 22,8 \\
\hline & 60 ve üstü & 30 & 5,1 \\
\hline & Toplam & 592 & 100 \\
\hline \multirow{4}{*}{ Eğitim Durumu } & Lisans & 380 & 64,2 \\
\hline & Yüksek lisans & 182 & 30,7 \\
\hline & Doktora & 30 & 5,1 \\
\hline & Toplam & 592 & 100 \\
\hline \multirow{5}{*}{ Sertifika } & A-1 & 230 & 38,9 \\
\hline & $\mathrm{A}-2$ & 202 & 34,1 \\
\hline & A-3 & 140 & 23,6 \\
\hline & A-4 & 20 & 3,4 \\
\hline & Toplam & 592 & 100 \\
\hline \multirow{4}{*}{ Kurum Türü } & Genel Bütçeli Kamu Kurumu & 201 & 34,0 \\
\hline & Özel Bütçeli Kamu Kurumu & 212 & 35,8 \\
\hline & Mahalli İdare & 179 & 30,2 \\
\hline & Toplam & 592 & 100 \\
\hline
\end{tabular}

Katılımcıların demografik özelliklerinden en fazla öne çıkan hususlara bakıldığında, ankete katılan 592 kişinin \%87,7'sinin erkek, \%37,5'inin 40-49 yaş aralığında, \%64,2'sinin lisans mezunu, \%38,9'unun A1 sertifikasına ve \%35,8'nin de özel bütçeli kamu kurumlarında çalıştıkları görülmektedir.

30 ve altı yaş aralığında iç denetçinin bulunmaması dikkat çekici bir husustur. Bunun nedeni kamu iç denetçisi aday belirleme başvuru şartları arasında adayın bir kamu kurumunda en az beş yıllık hizmet süresinin olması şeklinde açıklanabilir. 
5018 sayılı KMYKK'nın 65. maddesine göre, iç denetçi olabilmek için lisans mezunu olma şartı bulunmaktadır Dolayısıyla iç denetçilerin büyük bir bölümünün lisans mezunu olması beklenen bir durumdur. Burada üzerinde durulması gereken husus, yüksek lisans ve doktora mezunlarının oranlarıdır. Bu oranlara bakıldığında, katılımcıların belli bir bölümünün lisansüstü eğitim mezunu oldukları görülmektedir. İç denetçilerin lisansüstü eğitim mezunu olmaları, kamu iç denetçi sertifika derecelerinin artırılmasında dikkate alınan hususlardan biridir. Bu kriterin iç denetçileri lisansüstü eğitime yönlendiren önemli bir unsur olduğu söylenebilir.

Kamu kurumlarında, iç denetimde mesleki yeterlilik kıdem esasına göre değil, mesleki başarı ve yeteneğin temel alındığı sertifika sistemi ile ölçülmektedir. İç denetime geçiş sürecinde sertifikasyona dayalı bir anlayışın benimsenmesi evrensel nitelikte, özgüveni yüksek, emeğe saygıll, değişime ve gelişime açık iç denetçilerin yetişmesini sağlayacaktır. Söz konusu sertifikalar önem sırasına göre A-1, A-2, A-3 ve A-4 şeklinde derecelendirilmektedir. A-4 sertifikasına sahip olanların oranının çok az sayıda olmasının muhtemel nedeni, kamuda iç denetim sisteminin ve kamu iç denetçi sertifikası uygulamasının çok fazla bir geçmişinin olmamasından kaynaklanabilir.

4.2. İç Denetim Faaliyetlerinde Karşılaşılan Başlıca Sorunların Belirlenmesine Yönelik Bulguların Analizi

Çalışmanın bu kısmında kamu iç denetçilerinin iç denetim faaliyetini ifa ederken karşılaştıkları başlıca sorunlara ilişkin bulguların değerlendirilmesi ve hipotezlerin analizi yer almaktadır.

\subsection{1. İç Denetimde Genel Bağımsızlık Sorunu}

İç denetimde genel bağımsızlık sorununun olup olmadığını tespit etmek amacıyla sorulan sorulara iç denetçilerin verdikleri cevaplar Tablo 2'de yer almaktadır.

Tablo 2. İç Denetimde Genel Bağımsızlık Sorununa İlişskin Bulgular

\begin{tabular}{|c|c|c|c|c|c|c|c|c|c|c|c|c|}
\hline \multirow[t]{2}{*}{ İFADELER } & \multicolumn{2}{|c|}{ 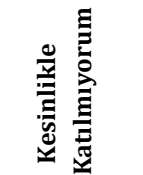 } & \multicolumn{2}{|c|}{ 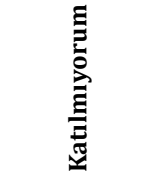 } & \multicolumn{2}{|c|}{ 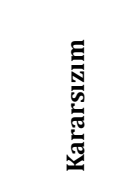 } & \multicolumn{2}{|c|}{ 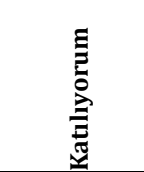 } & \multicolumn{2}{|r|}{ 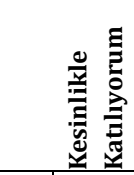 } & \multirow{2}{*}{ 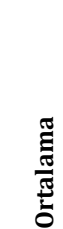 } & \multirow{2}{*}{ 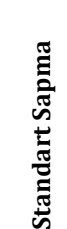 } \\
\hline & $\mathbf{n}$ & $\%$ & $\mathbf{n}$ & $\%$ & $\mathbf{n}$ & $\%$ & $\mathbf{n}$ & $\%$ & $\mathbf{n}$ & $\%$ & & \\
\hline $\begin{array}{l}\text { İç denetim birimimiz, } \\
\text { kurum üst } \\
\text { yöneticisinin dışında } \\
\text { başka bir yönetim } \\
\text { kademesinden de } \\
\text { zaman zaman talimat } \\
\text { alır. }\end{array}$ & 314 & 53,0 & 114 & 19,3 & 19 & 3,2 & 74 & 12,5 & 71 & 12,0 & 2,11 & 1,461 \\
\hline $\begin{array}{l}\text { İç denetim raporlarına } \\
\text { üst yönetici müdahale } \\
\text { eder. }\end{array}$ & 143 & 24,2 & 176 & 29,7 & 65 & 11,0 & 135 & 22,8 & 73 & 12,3 & 2,69 & 1,376 \\
\hline
\end{tabular}

Sayfa/Page | 75

IGU J. Soc. Sci., 4 (2), Spec. Iss. of ICEFM 2017, pp. 67-88. 
Sayfa/Page | 76

İGÜ Sos. Bil. Derg., 4 (2), ICEFM 2017 Özel Sayısı, ss. 67-88.

\begin{tabular}{|l|l|l|l|l|l|l|l|l|l|l|l|l|}
\hline $\begin{array}{l}\text { İç denetim yönergesi } \\
\text { ve meslek standartları } \\
\text { ile tanımlanmış iç } \\
\text { denetim faaliyeti, } \\
\text { kurumumda } \\
\text { öngörüldüğü şekilde } \\
\text { uygulanabilmektedir. }\end{array}$ & 57 & 9,6 & 110 & 18,6 & 105 & 17,7 & 267 & 45,1 & 53 & 9,0 & 3,25 & 1,148 \\
\hline $\begin{array}{l}\text { Kurumumda, iç } \\
\text { denetim faaliyetinin } \\
\text { bağımsılığın } \\
\text { engelleyecek } \\
\text { düzenleme ve } \\
\text { uygulamalar } \\
\text { mevcuttur. }\end{array}$ & 105 & 17,7 & 211 & 35,6 & 62 & 10,5 & 158 & 26,7 & 56 & 9,5 & 2,74 & 1,284 \\
\hline
\end{tabular}

Tablo 2 incelendiğinde; katılımcıların \%72,3'ü iç denetim birimlerinin üst yöneticinin dışında başka bir yönetim kademesinden talimat almadıklarını, $\% 53,9$ 'u hazırlanan raporlara üst yöneticinin müdahale etmediğini, \%54,1'i iç denetim faaliyetinin kurumlarında öngörüldüğü șekilde uygulandığını ve \%53,3'ü de iç denetim faaliyetlerinin bağımsızlığını engelleyecek düzenleme ve uygulamaların olmadığını belirtmiştir. Buna göre, üst yönetici dışında başka bir yönetim kademesinden talimat alma ifadesi hariç, diğer durumlar için elde edilen değerlerin \%50'lerde olması söz konusu sorunun halen devam ettiğini göstermektedir. Genel olarak bakıldığında iç denetimde genel bağımsızlığın sağlanması hususunda az da olsa olumlu bir gelişmenin olduğu söylenebilir.

İç denetimde genel bağımsızlık sorununa ilişkin hipotez; "H: Kamu Kurumlarının Bütçe Türleri İle İç Denetimde Genel Bağımsızlık Sorunu Arasında Anlamlı Bir Fark Vardır" ş̧eklinde düzenlenmiştir. Söz konusu hipotez için yapılan test sonuçları Tablo 3'de yer almaktadır.

Tablo 3. Kamu Kurumlarının Bütçe Türleri İle İç Denetimde Genel Bağımsızlık Sorunu Arasındaki Farklılıklara İlişkin Kruskal-Wallis Test Sonuçları

\begin{tabular}{|l|l|l|l|l|l|}
\hline $\begin{array}{l}\text { Bağımsız } \\
\text { Değişkenler }\end{array}$ & N & Sıra Ortalaması & $\chi^{2}$ & sd & P \\
\cline { 1 - 3 } Genel bütçeli & 201 & 318,10 & \multirow{2}{*}{6,904} & 2 & 0,032 \\
\cline { 1 - 3 } & 212 & 274,23 & & & \\
\cline { 1 - 3 } & 179 & 298,62 & & \\
\hline
\end{tabular}

Buna göre $\mathrm{H}_{1}$ hipotezi kabul edilmiştir $(\mathrm{P}=0,032<\alpha=0,05)$. Yani iç denetimde genel bağımsızlık sorunu ile kamu kurumlarının bütçe türleri arasında \%5 anlamlılık düzeyinde istatistiksel olarak anlamlı bir fark bulunmuştur. Kurumların sıra ortalamalarına bakıldığında, genel bütçeli kurumlarda söz konusu sorunla karşılaşma durumunun daha fazla olduğu söylenebilir. 


\subsection{2. İç Denetimde Fonksiyonel Bağımsızlık Sorunu}

İç denetim birimlerinin ne ölçüde fonksiyonel bağımsızlığa kavuştuğunu belirlemek için sorulan sorulara katılımcıların verdikleri cevaplar Tablo 4'de yer almaktadır.

Tablo 4. İç Denetimde Fonksiyonel Bağımsızlık Sorununa İlişkin Bulgular

\begin{tabular}{|c|c|c|c|c|c|c|c|c|c|c|c|c|}
\hline \multirow[t]{2}{*}{ İFADELER } & \multicolumn{2}{|c|}{ 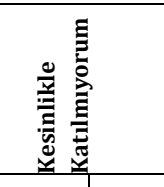 } & \multicolumn{2}{|c|}{ 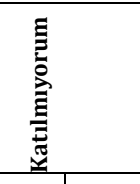 } & \multicolumn{2}{|c|}{ 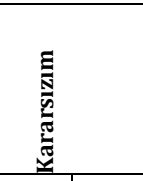 } & \multicolumn{2}{|c|}{ 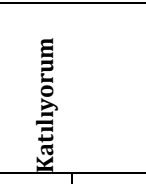 } & \multicolumn{2}{|c|}{ 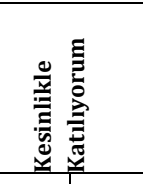 } & \multirow{2}{*}{ 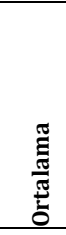 } & \multirow{2}{*}{ 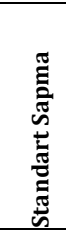 } \\
\hline & $\mathbf{n}$ & $\%$ & $\mathbf{n}$ & $\%$ & $\mathbf{n}$ & $\%$ & n & $\%$ & $\mathrm{n}$ & $\%$ & & \\
\hline $\begin{array}{l}\text { Kurumumda iç } \\
\text { denetim biriminin } \\
\text { önemli bulduğu } \\
\text { konularda üst } \\
\text { yöneticiyi } \\
\text { bilgilendiren ve } \\
\text { bilgi akışının } \\
\text { zamanında } \\
\text { gerçekleştirilmesin } \\
\text { i sağlayan bir } \\
\text { iletişim } \\
\text { mekanizması } \\
\text { mevcuttur. }\end{array}$ & 66 & 11,1 & 136 & 23,0 & 112 & 18,9 & 203 & 34,3 & 75 & 12,7 & 3,14 & 1,228 \\
\hline $\begin{array}{l}\text { Üst yöneticimiz, } \\
\text { yönetim süreçleri } \\
\text { ile denetim } \\
\text { sonuçlarını, yorum } \\
\text { ve önerileri } \\
\text { tartışmak için iç } \\
\text { denetçilerle özel } \\
\text { görüşmeler yapar. }\end{array}$ & 123 & 20,8 & 199 & 33,6 & 67 & 11,3 & 142 & 24,0 & 61 & 10,3 & 2,69 & 1,315 \\
\hline $\begin{array}{l}\text { Kurumumda iç } \\
\text { denetim biriminin } \\
\text { kendisine ait } \\
\text { bütçesinin olması, } \\
\text { iç denetimin } \\
\text { fonksiyonel } \\
\text { bağımsızlı̆̆ için } \\
\text { önemlidir. }\end{array}$ & 41 & 6,9 & 49 & 8,3 & 52 & 8,8 & 200 & 33,8 & 250 & 42,2 & 3,96 & 1,211 \\
\hline $\begin{array}{l}\text { Denetim } \\
\text { faaliyetlerinin } \\
\text { planlanması, } \\
\text { yürütülmesi, } \\
\text { raporlanması ve } \\
\text { izlenmesine ilişkin } \\
\text { görevlerin yerine } \\
\text { getirilmesinde iç } \\
\text { denetim birimi } \\
\text { bağımsız olarak } \\
\text { hareket eder. }\end{array}$ & 46 & 7,8 & 86 & 14,5 & 60 & 10,1 & 273 & 46,1 & 127 & 21,5 & 3,59 & 1,196 \\
\hline $\begin{array}{l}\text { İç denetim birim } \\
\text { başkanlıklarının } \\
\text { teşkilat } \\
\text { kanunlarında yer } \\
\text { alması iç denetimin } \\
\text { fonksiyonel } \\
\text { bağımsızlı̆̆ için } \\
\text { önemlidir. }\end{array}$ & 38 & 6,4 & 39 & 6,6 & 38 & 6,4 & 139 & 23,5 & 338 & 57,1 & 4,18 & 1,202 \\
\hline
\end{tabular}

Sayfa/Page | 77

GU J. Soc. Sci.,

4 (2), Spec. Iss. of ICEFM 2017,

pp. 67-88. 
Sayfa/Page | 78

İGÜ Sos. Bil. Derg., 4 (2), ICEFM 2017 Özel Sayısı, ss. 67-88

Tablo 4'e bakıldığında; katılımcıların \%47'sinin iç denetim birimlerinin önemli olduğunu düşündüğü konularda üst yönetime zamanında bilgi akışını sağlayan bir iletişim mekanizmasının olduğunu, \%76'sı iç denetim birimlerinin fonksiyonel bağımsızlığının sağlanabilmesi için kendisine ait bir bütçesinin olması gerektiğini, \% 67,6'sı iç denetim faaliyeti sürecinin ifa edilmesinde birimlerinin bağımsız olarak hareket ettiğini ve \%80,6'sı fonksiyonel bağımsızlık için iç denetim birim başkanlıklarının teşkilat kanunlarında yer alması gerektiğini belirtmiştir. Ayrıca iç denetçilerin $\% 54,4$ 'ü üst yöneticilerinin yönetim süreçleri ile denetim sonuçlarını değerlendirmek için kendileriyle özel görüşme yapmadıklarını ifade etmişlerdir.

Bu sonuçlara göre, 5018 sayılı Kanunda (Madde 64) öngörüldüğünün aksine, iç denetim birim başkanıyla üst yönetici arasında gerekli iletişimin sağlanamadığı görülmektedir. Nitekim uygulama esnasında katılımcıların önemli bir kısmı, denetim faaliyetleri ile ilgili konuları üst yöneticiden ziyade üst yöneticiye yakın diğer yöneticilerle görüştüklerini ifade etmişlerdir.

İç denetimde fonksiyonel bağımsızlık sorununa ilişkin hipotez; " $\mathbf{H}_{2}$ : Kamu Kurumlarının Bütçe Türleri İle İç Denetimde Fonksiyonel Bağımsızlık Sorunu Arasında Anlamlı Bir Fark Vardır" şeklinde düzenlenmiştir. Söz konusu hipotez için yapılan test sonuçları Tablo 5'te yer almaktadır.

Tablo 5. Kamu Kurumlarının Bütçe Türleri İle İç Denetimde Fonksiyonel Bağımsızlık Sorunu Arasındaki Farklılıklara İlişkin Kruskal-Wallis Test Sonuçları

\begin{tabular}{|l|l|l|l|l|l|}
\hline Bağımsız Değişkenler & N & Sıra Ortalaması & $\chi^{2}$ & sd & P \\
\cline { 1 - 3 } Genel bütçeli & 201 & 282,51 & & & \\
\cline { 1 - 3 } & 212 & 318,59 & 5,597 & 2 & \multirow{2}{*}{0,061} \\
\cline { 1 - 3 } & 179 & 286,04 & & & \\
\hline
\end{tabular}

İç denetimde fonksiyonel bağımsızlık sorunu ile kamu kurumlarının bütçe türleri arasında \%5 anlamlılık düzeyinde istatistiksel olarak anlamlı bir fark bulunamamıştır. Yani $\mathrm{H}_{2}$ hipotezi reddedilmiştir $(\mathrm{P}=0,061>\alpha=0,05)$.

\subsection{3. İç Denetçilerin Görev, Yetki ve Statüleri ile İlgili Sorunlar}

İç denetçilerin görev, yetki ve statü kapsamında ne tür sorunlarla karşılaştıklarını belirlemek amacıyla yöneltilen sorulara iç denetçilerin vermiş oldukları cevaplar Tablo 6'da yer almaktadır. 
Tablo 6. İç Denetçilerin Görev, Yetki ve Statü Sorunlarına İlişkin Bulgular

\begin{tabular}{|c|c|c|c|c|c|c|c|c|c|c|c|c|}
\hline \multirow[t]{2}{*}{ İFADELER } & \multicolumn{2}{|c|}{ 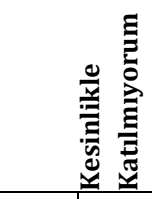 } & \multicolumn{2}{|c|}{ 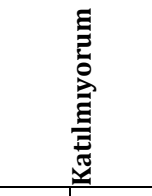 } & \multicolumn{2}{|c|}{ 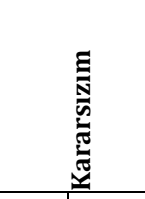 } & \multicolumn{2}{|c|}{ 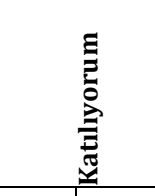 } & \multicolumn{2}{|r|}{ 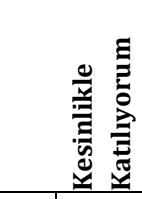 } & \multirow{2}{*}{ } & \multirow{2}{*}{ 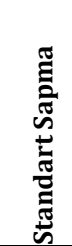 } \\
\hline & $\mathbf{n}$ & $\%$ & $\mathbf{n}$ & $\%$ & $\mathbf{n}$ & $\%$ & $\mathbf{n}$ & $\%$ & $\mathbf{n}$ & $\%$ & & \\
\hline $\begin{array}{l}\text { İç denetim birimi } \\
\text { başkanının } \\
\text { (yöneticisinin) } \\
\text { mevcut statüsü, iç } \\
\text { denetimin gelişimi } \\
\text { için uygundur. }\end{array}$ & 114 & 19,3 & 163 & 27,5 & 99 & 16,7 & 126 & 21,3 & 90 & 15,2 & 2,86 & 1,360 \\
\hline $\begin{array}{l}\text { Kurumumda iç } \\
\text { denetim birimi, } \\
\text { yolsuzluklarla ve } \\
\text { suiistimallerle } \\
\text { mücadelede etkin } \\
\text { bir rol } \\
\text { üstlenmiștir. }\end{array}$ & 66 & 11,1 & 160 & 27,0 & 163 & 27,5 & 155 & 26,2 & 48 & 8,1 & 2,93 & 1,140 \\
\hline $\begin{array}{l}\text { Kurumumda iç } \\
\text { denetimin rolü ile } \\
\text { mevcut teftiş } \\
\text { kurulları ve diğer } \\
\text { denetim birimleri } \\
\text { arasındaki } \\
\text { farklılıklar } \\
\text { tanımlanmıştır. }\end{array}$ & 121 & 20,4 & 180 & 30,4 & 97 & 16,4 & 156 & 26,4 & 38 & 6,4 & 2,68 & 1,242 \\
\hline $\begin{array}{l}\text { Kurumumda risk } \\
\text { iștahının } \\
\text { belirlenmesi, risk } \\
\text { yönetim } \\
\text { süreçlerinin } \\
\text { düzenlenmesi ve } \\
\text { riskler üzerine } \\
\text { yönetim güvencesi } \\
\text { verilmesi gibi } \\
\text { faaliyetler iç } \\
\text { denetim birimi } \\
\text { tarafından } \\
\text { yapılmaktadır. }\end{array}$ & 126 & 21,3 & 200 & 33,8 & 80 & 13,5 & 129 & 21,8 & 57 & 9,6 & 2,65 & 1,292 \\
\hline
\end{tabular}

Tablo 6 değerlendirildiğinde; iç denetçilerin \%46,8'i iç denetimin gelişimi için birim başkanlarının mevcut statüsünün uygun olmadığını, $\% 38,1$ 'i yolsuzluk ve suiistimallerle mücadelede etkin bir rol üstlenmediklerini, $\% 50,8$ 'i iç denetimin rolü ile teftiş kurulları ve diğer denetim birimleri arasındaki farklılıkların tanımlanmadı̆̆ını, \%55,1'i kurumlarında risk iştahının belirlenmesi, risk yönetim süreçlerinin düzenlenmesi ve riskler üzerinde yönetim güvencesi verilmesi gibi faaliyetlerin iç denetim birimleri tarafından yapılmadığını ifade ettikleri görülmektedir.

Sayfa/Page | 79

IGU J. Soc. Sci., 4 (2), Spec. Iss. of ICEFM 2017, pp. 67-88. 
Sayfa/Page | 80

İGÜ Sos. Bil. Derg., 4 (2), ICEFM 2017 Özel Sayısı, ss. 67-88.

Yolsuzluk ve suiistimallerle mücadele konusu, iç denetimin görev kapsamında değildir. Bu kapsamda düşünüldüğünde, bu konuyla ilgili ortaya çıkan sonucun tatminkâr düzeyde olmadığı söylenebilir. Çünkü aksini düşünenlerin oranı ile arada ciddi bir farkın olmadığı görülmektedir. Diğer bir husus ise, iç denetim, teftiş kurulları ve diğer denetim birimleri arasındaki görev ve yetki karmaşasının giderilmesidir. Bu yöndeki bulgular da söz konusu sorunun tam anlamıyla giderilmediğini işaret etmektedir.

Daha önce de ifade edildiği üzere, risk yönetimiyle ilgili faaliyetler üst yönetimin sorumluluğu altındadır. Burada iç denetimin rolü sadece risklerle ilgili güvence vermektir. $\mathrm{Bu}$ yöndeki bulguların \%50'lerde olması, iç denetçilerin görev kapsamı dışındaki işleri yaptıklarını göstermektedir.

İç denetçilerin görev, yetki ve statü sorunlarına ilişkin hipotez; "H $\mathbf{H}_{3}$ : Kamu Kurumlarının Bütçe Türleri İle İç Denetçilerin Görev, Yetki ve Statüleriyle İlgili Sorunlar Arasında Anlamlı Bir Fark Vardır" şeklinde düzenlenmiştir. Söz konusu hipotez için yapılan test sonuçları Tablo 7'de yer almaktadır.

Tablo 7. Kamu Kurumlarının Bütçe Türleri İle İç Denetçilerin Görev, Yetki ve Statüleriyle İlgili Sorunlar Arasındaki Farklılıklara İlişkin Kruskal-Wallis Test Sonuçları

\begin{tabular}{|l|l|l|l|l|l|}
\hline $\begin{array}{l}\text { Bağımsız } \\
\text { Değişkenler }\end{array}$ & N & $\begin{array}{l}\text { Sıra } \\
\text { Ortalaması }\end{array}$ & $\chi^{2}$ & sd & P \\
\hline Genel bütçeli & 201 & 261,08 & \multirow{2}{*}{14,969} & 2 & 0,001 \\
\hline Özel bütçeli & 212 & 304,15 & & 327,21 & \\
\hline Mahalli idare & 179 & 3 &
\end{tabular}

Buna göre $\mathrm{H}_{3}$ hipotezi kabul edilmiştir $(\mathrm{P}=0,001<\alpha 0,05)$. Yani iç denetim faaliyetleri yürütülürken iç denetçilerin karşılaştıkları görev, yetki ve statü sorunları ile kamu kurumlarının bütçe türleri arasında \%5 anlamlılık düzeyinde istatistiksel olarak anlamlı bir fark bulunmuştur. Kurumların sıra ortalamalarına bakıldığında mahalli idarelerde söz konusu sorunla karşılaşma durumunun daha fazla olduğu söylenebilir.

\subsection{4. İDKK'nın Kurumsal Yapısı ile İlgili Sorunlar}

İDKK'nın hem kurumsal hem de idari yapısından kaynaklı sorunları tespit etmeye yönelik sorulan sorulara katılımcıların verdikleri cevaplar Tablo 8'de yer almaktadır. 
Tablo 8. İDKK'nın Kurumsal Yapısı ile İlgili Sorunlara İlişkin Bulgular

\begin{tabular}{|c|c|c|c|c|c|c|c|c|c|c|c|c|}
\hline \multirow[t]{2}{*}{ İFADELER } & \multicolumn{2}{|c|}{$\begin{array}{l} \\
\end{array}$} & \multicolumn{2}{|c|}{ 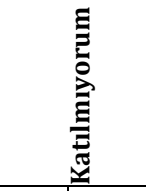 } & \multicolumn{2}{|r|}{ 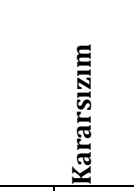 } & \multicolumn{2}{|r|}{ E } & \multicolumn{2}{|c|}{ 竭 } & \multirow{2}{*}{ 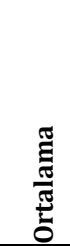 } & \multirow{2}{*}{ 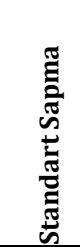 } \\
\hline & $\mathbf{n}$ & $\%$ & $\mathbf{n}$ & $\%$ & $\mathbf{n}$ & $\%$ & $\mathbf{n}$ & $\%$ & $\mathbf{n}$ & $\%$ & & \\
\hline $\begin{array}{l}\text { İDKK'nın mevcut } \\
\text { kurumsal kapasitesi iç } \\
\text { denetimin gelişimi için } \\
\text { yeterlidir. }\end{array}$ & 199 & 33,6 & 203 & 34,3 & 92 & 15,5 & 74 & 12,5 & 24 & 4,1 & 2,19 & 1,150 \\
\hline $\begin{array}{l}\text { İDKK'nın mevcut idari } \\
\text { yapısı iç denetimin } \\
\text { gelişimi için yeterlidir. }\end{array}$ & 205 & 34,6 & 204 & 34,5 & 96 & 16,2 & 65 & 11,0 & 22 & 3,7 & 2,15 & 1,124 \\
\hline
\end{tabular}

Sayfa/Page | 81

IGU J. Soc. Sci., 4 (2), Spec. Iss. of ICEFM 2017, pp. 67-88.

Tablo 8 incelendiğinde; iç denetçilerin \%67,9'u İDKK'nın mevcut kurumsal kapasitesinin ve \%69,1'i de kurulun idari yapısının iç denetimin gelişimi için yeterli olmadığını ifade etmişlerdir.

Yukarıda elde edilen sonuçlar, kurulun gerek kurumsal kapasitesinin gerekse idari yapısının, iç denetimin gelişimi için uygun bir zemin hazırlamadığını göstermektedir. Katılımcılarla yapılan görüşmelerde ise, İDKK'nın ayrı bir tüzel kişiliğe kavuşturulması ve kurul üyelerinin tüm mesailerini iç denetimin gelişimi için harcamaları gerektiği vurgulanmıştır.

İDKK'nın kurumsal yapısıyla ilgili sorunlara ilişkin hipotez; "H4: Kamu Kurumlarının Bütçe Türleri İle İDKK'nın Kurumsal Yapısıyla İlgili Sorunlar Arasında Anlamlı Bir Fark Vardır” şeklinde düzenlenmiştir. Söz konusu hipotez için yapılan test sonuçları Tablo 9'da yer almaktadır.

Tablo 9. Kamu Kurumlarının Bütçe Türleri İle İDKK'nın Kurumsal Yapısıyla İlgili Sorunlar Arasındaki Farklılıklara İlişsin Kruskal-Wallis Test Sonuçları

\begin{tabular}{|l|l|l|l|l|l|}
\hline $\begin{array}{l}\text { Bağımsız } \\
\text { Değişkenler }\end{array}$ & $\mathbf{N}$ & $\begin{array}{l}\text { Sıra } \\
\text { Ortalaması }\end{array}$ & $\chi^{2}$ & sd & P \\
\cline { 1 - 3 } Genel bütçeli & 201 & 297,25 & \multirow{2}{*}{0,284} & 2 & \multirow{2}{*}{0,868} \\
\cline { 1 - 3 } & 212 & 292,04 & & \\
\cline { 1 - 3 } & 179 & 300,94 & &
\end{tabular}

Buna göre $\mathrm{H}_{4}$ hipotezi reddedilmiştir $(\mathrm{P}=0,868>\alpha=0,05)$. Yani İDKK'nın kurumsal yapısıyla ilgili sorunlar ile kamu kurumlarının bütçe türleri arasında $\% 5$ anlamlılık düzeyinde istatistiksel olarak anlamlı bir fark bulunamamıştır. 
Sayfa/Page | 82

İGÜ Sos. Bil. Derg., 4 (2), ICEFM 2017 Özel Sayısı ss. $67-88$

\subsection{5. İç Denetçilerin Yetkinliği ve Sayısı ile İlgili Sorunlar}

İç denetçilerin yetkinliği ve sayısıyla ilgili sorununun olup olmadığını tespit etmek için sorulan sorulara iç denetçilerin verdikleri cevaplar Tablo 10 'da yer almaktadır.

Tablo 10. İç Denetçilerin Yetkinliği ve Sayısı ile İlgili Sorunlara İlişkin

Bulgular

\begin{tabular}{|c|c|c|c|c|c|c|c|c|c|c|c|c|}
\hline \multirow[t]{2}{*}{ İFADELER } & \multicolumn{2}{|c|}{ 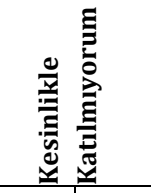 } & \multicolumn{2}{|c|}{ 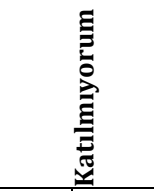 } & \multicolumn{2}{|r|}{ 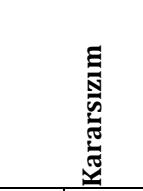 } & \multicolumn{2}{|c|}{ 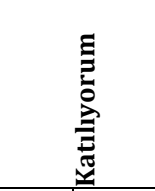 } & \multicolumn{2}{|c|}{ 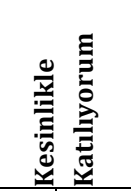 } & \multirow{2}{*}{ 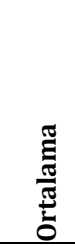 } & \multirow{2}{*}{ 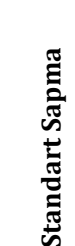 } \\
\hline & $\mathbf{n}$ & $\%$ & $\mathbf{n}$ & $\%$ & $\mathbf{n}$ & $\%$ & $\mathbf{n}$ & $\%$ & $\mathbf{n}$ & $\%$ & & \\
\hline $\begin{array}{l}\text { Kurumumuz iç } \\
\text { denetim birimi, iç } \\
\text { denetim faaliyeti } \\
\text { için gerekli } \\
\text { yeteneğe ve } \\
\text { tecrübeye sahiptir. }\end{array}$ & 40 & 6,8 & 99 & 16,7 & 86 & 14,5 & 282 & 47,6 & 85 & 14,4 & 3,46 & 1,130 \\
\hline $\begin{array}{l}\text { Kurumumuz iç } \\
\text { denetim birimi, } \\
\text { yeterli sayıda iç } \\
\text { denetçiden } \\
\text { oluşmaktadır. }\end{array}$ & 132 & 22,3 & 154 & 26,0 & 62 & 10,5 & 176 & 29,7 & 68 & 11,5 & 2,82 & 1,371 \\
\hline
\end{tabular}

Tablo 10'a bakıldığında; katılımcıların \%62'si birimlerinde iç denetim faaliyetini başarılı bir șekilde yapabilecek, gerekli yeteneğe ve tecrübeye sahip kişilerin bulunduğunu ancak \%48,3'ü de birimlerinde yeterli sayıda iç denetçinin olmadığını belirtmişlerdir.

Kamu kurumlarına atanması gereken toplam iç denetçi sayısı 2075 iken, atanmışların sayısı 963'tür. Doluluk oranının yaklaşık olarak \%46'larda olduğu görülmektedir. Bu oran da yukarıdaki sonucu destekler niteliktedir.

İç denetçilerin yetkinliği ve sayısıyla ilgili sorunlara ilişkin hipotez; "H5: Kamu Kurumlarının Bütçe Türleri İle İç Denetçilerin Yetkinliği Ve Sayısıyla İlgili Sorunlar Arasında Anlamlı Bir Fark Vardır" şeklinde düzenlenmiştir. Söz konusu hipotez için yapılan test sonuçları Tablo 11'de yer almaktadır. 
Tablo 11. Kamu Kurumlarının Bütçe Türleri İç Denetçilerin Yetkinliği ve Sayısıyla İlgili Sorunlar Arasındaki Farklılıklara İlişkin Kruskal-Wallis Test Sonuçları

\begin{tabular}{|l|l|l|l|l|l|}
\hline $\begin{array}{l}\text { Bağımsız } \\
\text { Değişkenler }\end{array}$ & N & $\begin{array}{l}\text { Sıra } \\
\text { Ortalaması }\end{array}$ & $\chi^{2}$ & sd & P \\
\cline { 1 - 3 } Genel bütçeli & 201 & 302,96 & \multirow{2}{*}{1,557} & 2 & 0,459 \\
\cline { 1 - 3 } & 212 & 301,45 & & & \\
\cline { 1 - 3 } & 179 & 283,38 & & & \\
\hline
\end{tabular}

Sayfa/Page | 83

IGU J. Soc. Sci., 4 (2), Spec. Iss. of ICEFM 2017, pp. 67-88.

Buna göre $\mathrm{H}_{5}$ hipotezi reddedilmiştir $(\mathrm{P}=0,459>\alpha=0,05)$. Yani iç denetçilerin yetkinliği ve sayısı ile ilgili sorunlar ile kamu kurumlarının bütçe türleri arasında \%5 anlamlılık düzeyinde istatistiksel olarak anlamlı bir fark bulunamamıştır.

\subsection{6. İç Denetçilerin Özlük Hakları İle İlgili Sorunlar}

Tablo 12'de iç denetçilerin özlük haklarıyla ilgili sorunlara ilişkin verdikleri cevaplar yer almaktadır.

Tablo 12. İç Denetçilerin Özlük Hakları ile İlgili Sorunlara İlişkin Bulgular

\begin{tabular}{|c|c|c|c|c|c|c|c|c|c|c|c|c|}
\hline \multirow[t]{2}{*}{ İFADELER } & \multicolumn{2}{|c|}{ 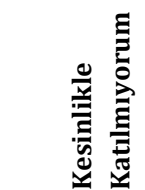 } & \multicolumn{2}{|c|}{ 离 } & \multicolumn{2}{|r|}{ 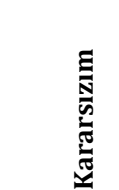 } & \multicolumn{2}{|c|}{ 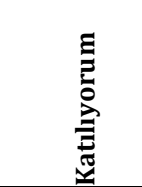 } & \multicolumn{2}{|c|}{ 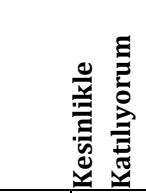 } & \multirow{2}{*}{ 营 } & \multirow{2}{*}{ 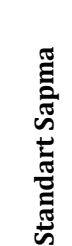 } \\
\hline & $\mathbf{n}$ & $\%$ & $\mathbf{n}$ & $\%$ & $\mathbf{n}$ & $\%$ & $\mathbf{n}$ & $\%$ & $\mathbf{n}$ & $\%$ & & \\
\hline $\begin{array}{l}\text { Kurumumda görev } \\
\text { tahsisli konut } \\
\text { verilecek kişiler } \\
\text { arasında iç } \\
\text { denetçiler } \\
\text { sayılmaktadır. }\end{array}$ & 231 & 39,0 & 140 & 23,6 & 43 & 7,3 & 95 & 16,0 & 83 & 14,0 & 2,42 & 1,480 \\
\hline $\begin{array}{l}\text { Kurumumda iç } \\
\text { denetçiler eski } \\
\text { görev } \\
\text { unvanlarından daha } \\
\text { düşük ücret } \\
\text { almaktadır. }\end{array}$ & 140 & 23,6 & 169 & 28,5 & 46 & 7,8 & 124 & 20,9 & 113 & 19,1 & 2,83 & 1,477 \\
\hline
\end{tabular}

Tablo 12 incelendiğinde; katılımcıların \%62,6'sı kurumlarında görev tahsisli konut verilecekler arasında olmadıklarını ve \%52,1'i de eski görev unvanlarında daha düşük ücret aldıklarını ifade etmişler. Buna göre, iç denetçilerin özlük haklarıyla ilgili çözülmesi gereken sorunların olduğu söylenebilir. 
Sayfa/Page | 84

İGÜ Sos. Bil. Derg., 4 (2), ICEFM 2017 Özel Sayısı ss. 67-88

İç denetçilerin özlük haklarıyla ilgili sorunlara ilişkin hipotez; "H6: Kamu Kurumlarının Bütçe Türleri İle İç Denetçilerin Özlük Haklarıyla İlgili Sorunlar Arasında Anlamlı Bir Fark Vardır" şeklinde düzenlenmiştir. Söz konusu hipotez için yapılan test sonuçları Tablo 13'de yer almaktadır.

Tablo 13. Kamu Kurumlarının Bütçe Türleri ile İç Denetçilerin Özlük Haklarıyla İlgili Sorunlar Arasındaki Farklılıklara İlişskin Kruskal-Wallis Test Sonuçları

\begin{tabular}{|l|l|l|l|l|l|}
\hline $\begin{array}{l}\text { Bağımsız } \\
\text { Değişkenler }\end{array}$ & N & $\begin{array}{l}\text { Sıra } \\
\text { Ortalaması }\end{array}$ & $\chi^{2}$ & sd & P \\
\cline { 1 - 3 } Genel bütçeli & 201 & 333,91 & \multirow{2}{*}{19,960} & 2 & 0,000 \\
\cline { 1 - 2 } & 212 & 259,70 & & & \\
\hline Mahalli idare & 179 & 298,08 & & & \\
\hline
\end{tabular}

Buna göre kurumlarının bütçe türleri değişkeni ile iç denetçilerin özlük hakları ile ilgili karşılaştıkları sorunlar arasında \%5 anlamlılık düzeyinde istatistiksel olarak anlamlı bir fark bulunmuştur $(\mathrm{P}=0,0000<\alpha=0,05)$. Yani $\mathrm{H}_{6}$ hipotezi kabul edilmiştir. Kurumların sıra ortalamalarına bakıldığında genel bütçeli kurumlarda söz konusu sorunla karşılaşma durumunun daha fazla olduğu söylenebilir.

\subsubsection{Raporlama ve Dış Denetimle İlgili Sorunlar}

Raporlama ve diş denetimle ilgili sorulan sorulara katılımcıların verdikleri cevaplar Tablo 14'de yer almaktadır.

Tablo 14. Raporlama ve Dıș Denetimle İlgili Sorunlara İlişkin Bulgular

\begin{tabular}{|c|c|c|c|c|c|c|c|c|c|c|c|c|}
\hline \multirow[t]{2}{*}{ İFADELER } & \multicolumn{2}{|c|}{ 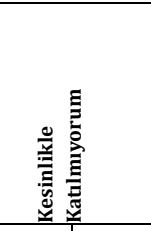 } & \multicolumn{2}{|c|}{ 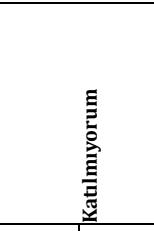 } & \multicolumn{2}{|c|}{$\begin{array}{l}\mathbb{E} \\
\bar{N} \\
\bar{N}\end{array}$} & \multicolumn{2}{|c|}{ 氞 } & \multicolumn{2}{|c|}{ 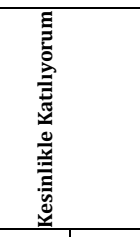 } & \multirow{2}{*}{$\begin{array}{l}\frac{\pi}{\tilde{E}} \\
\frac{\pi}{5} \\
\text { ț }\end{array}$} & \multirow{2}{*}{ 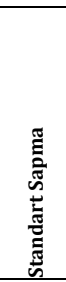 } \\
\hline & $\mathbf{n}$ & $\%$ & $\mathrm{n}$ & $\%$ & $\mathrm{n}$ & $\%$ & $\mathrm{n}$ & $\%$ & $\mathbf{n}$ & $\%$ & & \\
\hline $\begin{array}{l}\text { İç denetim birimi, } \\
\text { üst yönetici } \\
\text { dş̧ındaki başka } \\
\text { mercilere de } \\
\text { raporlama } \\
\text { yapabilmektedir. }\end{array}$ & 175 & 29,6 & 217 & 36,7 & 58 & 9,8 & 101 & 17,1 & 41 & 6,9 & 2,35 & 1,256 \\
\hline $\begin{array}{l}\text { İç denetim birimi } \\
\text { ile dış denetim } \\
\text { arasında işbirliği ve } \\
\text { iletissim } \\
\text { sağlanmaktadır. }\end{array}$ & 996 & 116,2 & 1136 & 223,0 & 1144 & 224,3 & 1164 & 227,7 & 552 & 88,8 & 22,90 & 11,224 \\
\hline
\end{tabular}


Tablo 14'e bakıldığında; iç denetçilerin $\% 66,3^{\prime}$ ü birimlerinin üst yöneticilerin dışında başka mercilere raporlama yapmadıklarını ve \%39,2'si de iç denetim ile dış denetim arasında işbirliği ve iletişimin olmadığını belirtmişler. Sonuçlar genel olarak değerlendirildiğinde üst yönetim dışında başka mercilere raporlamanın çok fazla yapılmadığı ve iç denetim ile dış denetim arasında yeterince koordinasyonun sağlanamadığı tespit edilmiştir.

Raporlama ve dış denetimle ilgili sorunlara ilişkin hipotez; “H: Kamu Kurumlarının Bütçe Türleri İle Raporlama ve Dış Denetimle İlgili Sorunlar Arasında Anlamlı Bir Fark Vardır" şeklinde düzenlenmiştir. Söz konusu hipotez için yapılan test sonuçları Tablo 15 'te yer almaktadır.

Tablo 15. Kamu Kurumlarının Bütçe Türleri İle Raporlama ve Dış Denetimle İlgili Sorunlar Arasındaki Farklılıklara İlişkin Kruskal-Wallis Test Sonuçları

\begin{tabular}{|l|l|l|l|l|l|}
\hline Bağımsız Değişkenler & $\mathbf{N}$ & $\begin{array}{l}\text { Sıra } \\
\text { Ortalaması }\end{array}$ & $\chi^{2}$ & sd & P \\
\cline { 1 - 3 } Genel bütçeli & 201 & 297,96 & \multirow{2}{*}{1,200} & 2 & \multirow{2}{*}{0,549} \\
\cline { 1 - 3 } & 212 & 304,25 & & & \\
\cline { 1 - 3 } & 179 & 285,68 & &
\end{tabular}

Buna göre $\mathrm{H}_{7}$ hipotezi reddedilmiştir $(\mathrm{P}=0,549>\alpha=0,05)$. Yani raporlama ve dış denetimle ilgili sorunlar ile kamu kurumlarının bütçe türleri arasında $\% 5$ anlamlılık düzeyinde istatistiksel olarak anlamlı bir fark bulunamamıştır.

\section{Sonuç}

Kamu kurumlarında geniş bir uygulama alanı bulunan iç denetim faaliyetlerinin yürütülmesi aşamasında karşılaşılan başlıca sorunların tespiti ve hangi kamu kurumlarında ne tür sorunların ön plana çıktığının tespit edilmesini amaçlayan bu çalışmanın ana kütlesini genel ve özel bütçeli kamu kurumları ile mahalli idarelerde çalışan iç denetçiler oluşturmaktadır. Söz konusu ana kütleye yapılan anket uygulaması sonucunda elde edilen bulgulara aşağıda yer verilmiştir.

İç denetim açısından genel anlamda bağımsızlık iç denetim biriminin direkt üst yöneticiye bağlı olması anlamını taşımaktadır. İç denetim birimi bulunan kamu kurumlarının organizasyon şemalarına bakıldığında, genel anlamda bağımsızlık ilkesinin gözetildiği görülmektedir. Ancak katılımcılar, iç denetim faaliyetlerinin yürütülmesinde genel bağımsızlık sorunun tam olarak aşılamadığını ifade etmişlerdir. Ayrıca kurumların bütçe türü değişkeni ile söz konusu sorun arasında istatiksel olarak anlamlı bir fark bulunmuştur. Genel bütçeli kamu kurumlarında (Bakanlıklar) genel bağımsızlık sorunuyla daha fazla karşılaşılldığı görülmüştür. Bu durumun iç denetim faaliyetlerinin en üst

Sayfa/Page | 85

IGU J. Soc. Sci., 4 (2), Spec. Iss. of ICEFM 2017, pp. 67-88. 
Sayfa/Page | 86

İGÜ Sos. Bil. Derg., 4 (2), ICEFM 2017 Özel Sayısı, ss. 67-88.

yönetici (Bakan) ile değil de alt kademedeki (Müsteşar) yöneticiler tarafından takip edilmesinden kaynaklandığı söylenebilir.

Fonksiyonel bağımsızlık, İç denetim birimi üst yönetimle veya diğer birimlerin yönetimiyle herhangi bir konu üzerinde farklı düşüncelere sahip olsalar bile, denetimine gerek duyduğu her türlü faaliyeti denetlemek konusunda bağımsız olmasını ifade eder. Burada şu husus ifade edilmelidir; iç denetim biriminin fonksiyonel açıdan bağımsız olması idari anlamda bağımsız olduğu anlamına gelmemektedir. Bu konu ile ilgili iç denetçiler, fonksiyonel bağımsızlığın sağlanması adına iç denetim birimlerinin kendilerine ait bütçelerinin olmasını ve ilgili teşkilat kanunlarında yer almalarının gerekliliği gibi hususlara dikkat çekmişlerdir.

Risk yönetimiyle ilgili faaliyetlerin yürütülmesi, yolsuzluk ve suiistimallerle mücadele gibi konular, iç deneticinin görevleri kapsamında değildir. Ancak bu konuyla ilgili elde edilen bulgular iç denetçilerin görevleri dışında başka işleri de yaptığını göstermektedir. Ayrıca kurumların bütçe türü değişkeni ile iç denetçilerin görev, yetki ve statüleriyle ilgili sorunlar arasında istatiksel olarak anlamlı bir fark bulunmuștur. Mahalli idarelerde (Belediyelerde) söz konusu sorunlarla karşılaşma durumunun daha fazla olduğu tespit edilmiştir. Bu durumun mahalli idarelerin siyasi yapısından, kurumsal yönetim eksikliğinden ve personel açı̆̆ından kaynaklandığı söylenebilir.

İç denetçilerin özlük hakları ile ilgili çeşitli sıkıntıların olduğu tespit edilmiştir. Ayrıca kurumların bütçe türü değişkeni ile iç denetçilerin özlük haklarıyla ilgili karşılaştıkları sorunlar arasında istatistiksel olarak anlamlı bir fark bulunmuştur. Genel bütçeli kurumlarda söz konusu sorunla karşılaşma durumunun daha fazla olduğu görülmüștür. Bu durum, daha önce çeşitli kurumlarda farklı mesleklerde çalışanların iç denetçiliği doğrudan atanmaları gibi sebeplerden kaynaklanabilir.

5018 sayılı kanunun 68. maddesinde kamu iç denetçisinin hazırladığı raporun gerek görülmesi halinde Sayıştay denetçilerine sunulabileceği belirtilmiştir. Ancak kamu idarelerinde bu hususun tam olarak uygulanmadığı tespit edilmiştir. Dış denetim, çalışmalarını genellikle iç denetim faaliyet sonuçları üzerinden yürütür. İç denetim de dış denetim bulgularını kendileri için bir rehber olarak kullanmalıdır. Dolayısıyla her iki taraf arasında işbirliği ve iletişimin olması gerekir. Ancak ortaya çıkan sonuç bu durumu destekler nitelikte değildir.

Özetle, kamu kurumları Türkiye'nin Avrupa Birliği'ne üyelik süreci kapsaminda açılan 32. Fasıl (Mali Kontrol) ile iç denetim sistemiyle tanışmışlardır. Bu süreçte iç denetim faaliyetlerinin kuruma değer katması amacıyla kurulan İDKK, iç denetimde başarıyı getirecek faaliyetlerin gerçekleştirilebilmesi için 5018 sayılı KMYKK kapsamında birçok çalışma 
hazırlamıştır. Tüm bu çalışmalara rağmen, elde edilen bulgulardan hareketle kamu kurumlarında iç denetim faaliyetlerinin yürütülmesini sekteye uğratan birçok sorunun halen devam ettiği söylenebilir.

\section{KAYNAKÇA}

ARENA, Marika, Arnaboldi, Michela, Azzone, Giovanni, "Internal audit in Italian Organizations A Multiple Case Study", Managerial Auditing Journal, 21(3), 2006, s.275-292.

ARSLAN, M. Cemil, Büyükșehir Belediyelerinin İç Denetim Uygulamaları, (1. Baskı), T.C. Marmara Belediyeler Birliği Yayını, Yayın No: 82, İstanbul 2014.

BOU-RAAD, Giselle, "Internal Auditors and A Value-Added Approach: The Business Regime”, Managerial Auditing Journal, 15(4), 2000, s. 182-187.

CARCELLO, Joseph V., Hermanson, Dana R., Raghunandan, K., "Factors Associated with U.S. Public Companies' Investment in Internal Auditing", Accounting Horizons, Vol: 19(2), June 2005, s. 69-84.

DOĞMUŞ, M. Didem, Avrupa Birliği'nde İç Denetim Sistemi, Maliye Bakanlığı Avrupa Birliği ve Dış İliş̧kiler Dairesi Başkanlığı Araştırma ve İnceleme Serisi: 2, Ankara 2010.

DOYRANGÖL, Nuran Cömert, "İşletme Çevresindeki Olumsuz Gelişmeler Karşısında İç Denetimin Yeri ve Önemi”, Mali Çözüm Dergisi, Sayı: 60, 2002, s.1-7.

GÖNÜLAÇAR, Şener, "İç Denetimde Hedefler ve Beklentiler", Mali Hukuk Dergisi, Sayı: 130, Temmuz 2007, s.1-21.

GÖNÜLAÇAR, Şener, "İç Denetimin Bürokratik Serencamı", Mali Hukuk Dergisi, Sayı: 35, Mayıs-Haziran 2008, s.1-21.

GÜRKAN, N. Zarifi (2009). Türk Kamu Mali Yönetiminde İç Denetim Ve İç Denetim Algısı, (Yayımlanmamış Yüksek Lisans Tezi), Süleyman Demirel Üniversitesi Sosyal Bilimler Enstitüsü, Isparta.

HÜNER, Deniz Barlas, Bağımsız Denetimde İç Kontrol ve İç Denetimin Rolü, (Yayımlanmamış Yüksek Lisans Tezi), Okan Üniversitesi, Sosyal Bilimler Enstitüsü, İstanbul, 2014.

www.ab.gov.tr

www.theiia.org 
Sayfa/Page | 88

İGÜ Sos. Bil. Derg., 4 (2), ICEFM 2017 Özel Sayısı ss. $67-88$

\section{Summary}

Today, an auditing approach has been adopted aiming at future and adding value to institutions. This approach has brought improvements such as increasing the authority and responsibilities of internal auditors, internal control internal control and starting to work integrated with corporate risk management systems. This situation has caused internal auditors to face some problems during the execution of internal audit activities. In this context, it is aimed to determine the main problems encountered during the execution of internal audit activities which have a wide application area in public institutions and to determine what problems are leading to which institutions. For this purpose, a questionnaire was applied to internal auditors working in all other public institutions, except Social Security Institutions

Survey forums used for collecting data in the study were applied to internal auditors during a training held by the Ministry of Finance in Antalya between 03-15 May 2016. The valid return was available from 592 of the 924 internal auditors who constituted the main mass of the study. This corresponds to a return rate of $64 \%$. The SPSS program was used to analyze the data obtained from the questionnaires. Through this program, descriptive statistical methods such as frequency, percentage, average are used. In addition, the hypotheses of working with the Kruskal-Wallis Test have been tested.

As a result, it has been found that many problems are encountered in carrying out internal audit activities in public institutions. In addition to general budgetary public institutions have reached the foreground of problems related to general independence in internal auditing and the personal rights of internal auditors and in the local administrations problems related to the duties, powers and statutes of internal auditors.

In summary, public institutions have met with Chapter 32 (Financial Control) and internal audit system, which was opened within the scope of Turkey's accession to the European Union. In this process, the Internal Audit Coordination Board, which was established with the purpose of adding value to the corporation, has prepared many studies within the scope of the Public Financial Management and Control Law No. 5018 in order to carry out the activities that will bring success in the internal audit. Despite all these studies, it can be said that there are still many problems that are affecting the execution of internal audit activities in public institutions with the action taken. 